\title{
Switching Between Anion-Binding Catalysis and Aminocatalysis with a Rotaxane Dual-Function Catalyst
}

DOI:

10.1021/jacs.7b04955

\section{Document Version}

Accepted author manuscript

Link to publication record in Manchester Research Explorer

\section{Citation for published version (APA):}

Eichstaedt, K., Jaramillo Garca, J., Leigh, D., Marcos Algaba, V., Pisano, S., \& Singleton, T. (2017). Switching Between Anion-Binding Catalysis and Aminocatalysis with a Rotaxane Dual-Function Catalyst. Journal of the American Chemical Society. https://doi.org/10.1021/jacs.7b04955

\section{Published in:}

Journal of the American Chemical Society

\section{Citing this paper}

Please note that where the full-text provided on Manchester Research Explorer is the Author Accepted Manuscript or Proof version this may differ from the final Published version. If citing, it is advised that you check and use the publisher's definitive version.

\section{General rights}

Copyright and moral rights for the publications made accessible in the Research Explorer are retained by the authors and/or other copyright owners and it is a condition of accessing publications that users recognise and abide by the legal requirements associated with these rights.

\section{Takedown policy}

If you believe that this document breaches copyright please refer to the University of Manchester's Takedown Procedures [http://man.ac.uk/04Y6Bo] or contact uml.scholarlycommunications@manchester.ac.uk providing relevant details, so we can investigate your claim.

\section{OPEN ACCESS}




\title{
Article
}

\author{
Switching Between Anion-Binding Catalysis and Amino- \\ catalysis with a Rotaxane Dual-Function Catalyst \\ Katarzyna Eichstaedt, Javier Jaramillo-Garcia, David A. Leigh, \\ Vanesa Marcos, Simone Pisano, and Thomas A. Singleton
}

J. Am. Chem. Soc., Just Accepted Manuscript • DOI: 10.1021/jacs.7b04955 • Publication Date (Web): 19 Jun 2017

Downloaded from http://pubs.acs.org on June 26, 2017

\section{Just Accepted}

"Just Accepted" manuscripts have been peer-reviewed and accepted for publication. They are posted online prior to technical editing, formatting for publication and author proofing. The American Chemical Society provides "Just Accepted" as a free service to the research community to expedite the dissemination of scientific material as soon as possible after acceptance. "Just Accepted" manuscripts appear in full in PDF format accompanied by an HTML abstract. "Just Accepted" manuscripts have been fully peer reviewed, but should not be considered the official version of record. They are accessible to all readers and citable by the Digital Object Identifier (DOI®). "Just Accepted" is an optional service offered to authors. Therefore, the "Just Accepted" Web site may not include all articles that will be published in the journal. After a manuscript is technically edited and formatted, it will be removed from the "Just Accepted" Web site and published as an ASAP article. Note that technical editing may introduce minor changes to the manuscript text and/or graphics which could affect content, and all legal disclaimers and ethical guidelines that apply to the journal pertain. ACS cannot be held responsible for errors or consequences arising from the use of information contained in these "Just Accepted" manuscripts. 


\section{INTRODUCTION}

Biology uses molecular machines in a broad range of molecular construction processes, from the ribosome ${ }^{1}$ to allosterically-regulated $^{2}$ enzymes. The latter is inspiring the development of 'smart' artificial catalysts' in which a stimulus is used to significantly alter the rate, or stereoor regioselective outcome, of a chemical reaction. ${ }^{4}$ However, systems that can switch between different catalytic groups that promote different chemical transformations remain scarce. ${ }^{5,6}$ We previously described ${ }^{7}$ a rotaxanebased $^{8}$ switchable aminocatalyst ${ }^{9}$ (1 'on' state/1- $\mathbf{H}^{+}$'off state) that modulates the rate of a range of organocatalyzed reactions via diverse activation pathways, ${ }^{7 \mathrm{~b}}$ including iminium-ion, enamine and trienamine, and even tandem iminium-enamine processes (Figure 1). Here we show that the 'off' state of the aminocatalyst also corresponds to an 'on' state for anion-binding catalysis, ${ }^{10}$ promoted by the presence of two triazolium groups on the rotaxane axle ${ }^{11}$ that work together to bind anions ${ }^{12,13}$ when the rotaxane macrocycle is located on the central ammonium group of the thread (Figure 2).

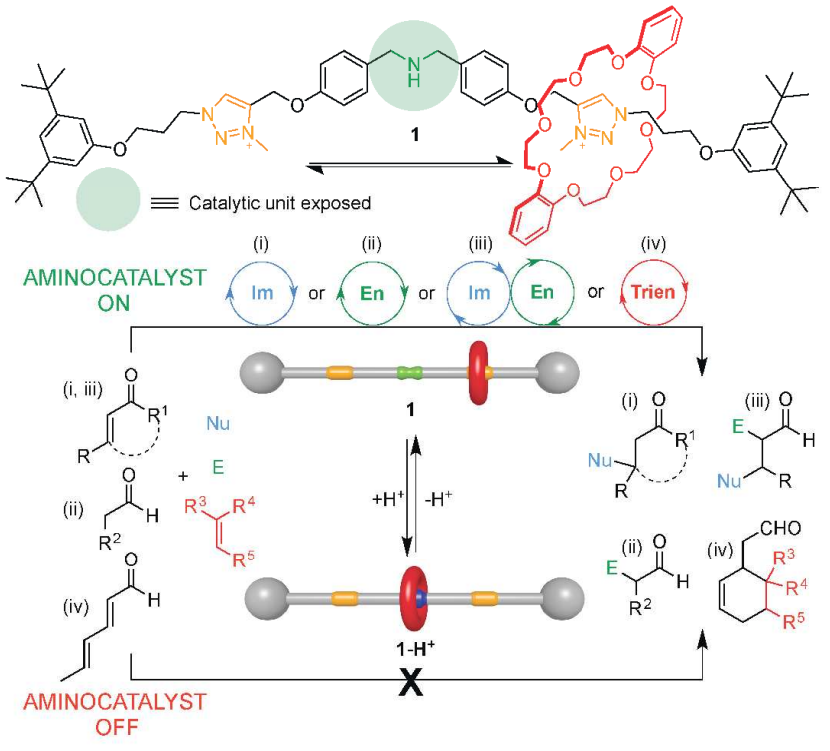

Figure 1. Acid-base switching of the position of the macrocycle in rotaxane $\mathbf{1}$ ('on' state) $/ \mathbf{1}-\mathbf{H}^{+}$('off' state) for controlling the rate of aminocatalysis via different activation pathways: (i) iminium-ion (Im); (ii) enamine (En); (iii) tandem iminium-enamine (Im-En); and (iv) trienamine (Trien). ${ }^{7}$

In the last few years, hydrogen bonding catalysis has emerged as a powerful tool for synthesis. ${ }^{14-16}$ The hydrogen bonding activation of neutral electrophiles, such as carbonyl or imine moieties, is well established, ${ }^{15}$ and hydrogen bonding activation of electrophilic ionic substrates by coordination to their counter anions is increas- 
ingly being exploited. ${ }^{15}$ Anion-binding catalysis generally utilizes catalysts based on strongly-polarized $\mathrm{N}-\mathrm{H}$ bonds, such as those in ureas, thioureas ${ }^{16}$ and thiophosphoramides. ${ }^{17}$ However, structures based on strong $\mathrm{O}-\mathrm{H}$ bonds, ${ }^{18}$ and even the cooperative action of less polarized $\mathrm{C}-\mathrm{H}^{19}$ or $\mathrm{C}-\mathrm{X}^{20}$ bonds, have also proved effective. Accordingly, we investigated whether the two triazolium groups of rotaxane $\mathbf{1}-\mathbf{H}^{+}$could act as an anion-binding catalyst for the in-situ generation of ionic intermediates, such as benzhydryl cations and oxonium ions via halide abstraction (Figure 2a). If so, the 'off' state of aminocatalyst (1$\mathbf{H}^{+}$) would also be an 'on' state for anion-binding catalysis, and the 'on' state for aminocatalysis (1) would be an 'off' state for anion-binding catalysis. The two different catalytic modes could, in principle, be activated in sequence, allowing the rotaxane-based molecular switch to promote tandem anion-binding/amino-catalyzed processes (Figure 2b).
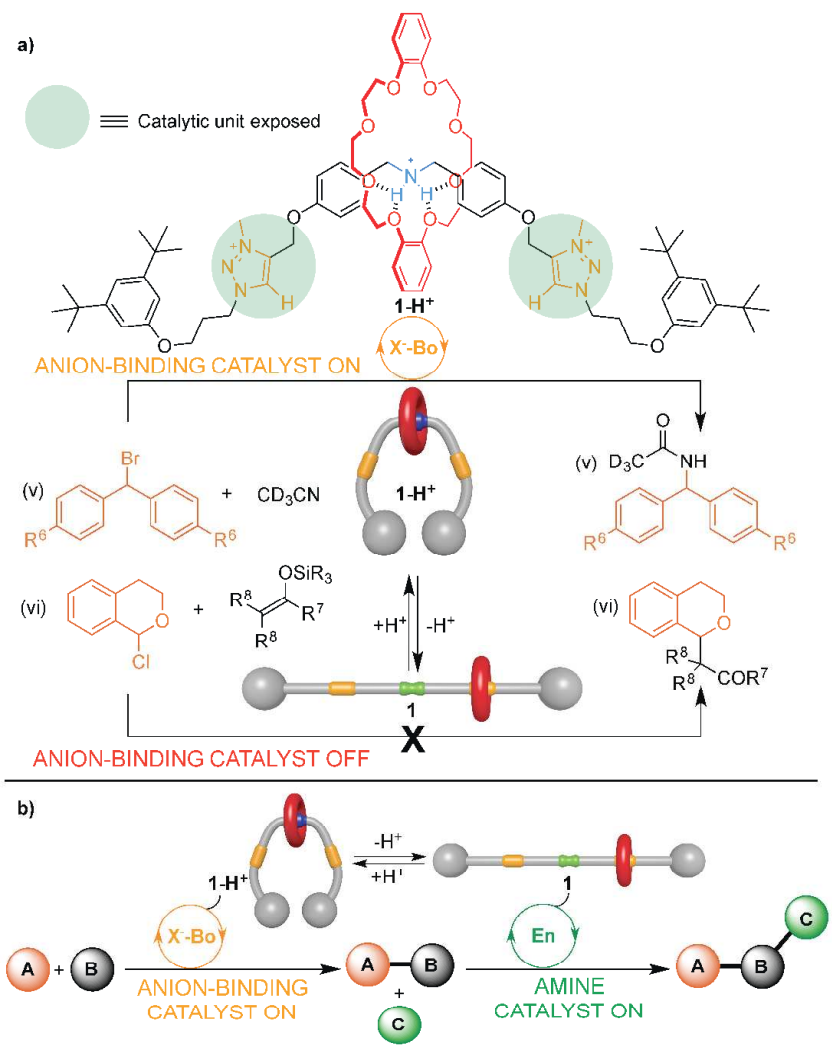

Figure 2. Acid-base switching of the position of the macrocycle in rotaxane $\mathbf{1}-\mathbf{H}^{+} / \mathbf{1}$ : (a) for controlling the rate of anionbinding-catalyzed reactions ( $\left.\mathrm{X}^{-}-\mathrm{Bo}\right)$; (b) for promoting tandem processes; an anion-binding-catalyzed reaction followed by an enamine-catalyzed reaction.

\section{RESULTS AND DISCUSSION}

Switchable rotaxane catalyst $\mathbf{1}-\mathbf{H}^{+} / \mathbf{1}$ consists of a dibenzo-24-crown-8 macrocycle locked onto a thread bearing a dibenzylamine/ammonium moiety and two triazolium rings, " and was prepared according to a previously established synthetic route. ${ }^{7}$ The bromide and chloride anion binding properties of rotaxanes $\mathbf{1}-\mathbf{H}^{+}$and $\mathbf{1}$ in $\mathrm{CD}_{3} \mathrm{CN}$ were investigated through ${ }^{1} \mathrm{H}$ NMR spectroscopy and titration experiments using the corresponding tetrabutylammoni- um halide salts (see Supporting Information). With rotaxane $\mathbf{1}-\mathbf{H}^{+}$, significant shifts in the resonances of the triazolium protons upon addition of $\mathrm{Bu}_{4} \mathrm{NCl}$ or $\mathrm{Bu}_{4} \mathrm{NBr}$ was observed by ${ }^{1} \mathrm{H}$ NMR spectroscopy. Titration experiments showed that rotaxane $\mathbf{1}-\mathbf{H}^{+}$forms 1:1 complexes with both bromide and chloride, with association constants $\left(K_{\mathrm{a}}\right)$ in $\mathrm{CD}_{3} \mathrm{CN}$ of $200 \mathrm{M}^{-1}$ in each case (see Supporting Information). ${ }^{21}$ In contrast, ${ }^{1} \mathrm{H}$ NMR spectroscopy showed little or no interaction between halide salts and the triazolium protons of rotaxane 1 (Supporting Information, Fig. S9 and $\left.\mathrm{S}_{10}\right)$.

Having established the halide-binding properties of the protonated rotaxane $\left(\mathbf{1}-\mathbf{H}^{+}\right)$and confirmed that halide binding is switched 'off' by changing the position of the macrocycle (i.e. in $\mathbf{1}$ ), we investigated the efficacy of the anion-binding state of the rotaxane as an anion-binding catalyst.

The Ritter reaction of bromodiarylmethane compounds and deuterated acetonitrile $\left(\mathrm{CD}_{3} \mathrm{CN}\right)^{20 c-e}$ was chosen for the investigation of the in situ generation of benzhydryl carbocation derivatives $\left(\mathrm{Ar}_{2} \mathrm{CH}^{+}\right)$formed through the rotaxane $\mathbf{1}-\mathbf{H}^{+}$-promoted cleavage of a carbon-bromide bond (Table 1). We first confirmed that the reaction of $5 \mathbf{a}$ with $\mathrm{CD}_{3} \mathrm{CN}$ does not proceed in the absence of the catalyst (Table 1, entry 1), and then carried out a series of experiments involving different potential reactionpromoting species (Table 1). Dibenzylamine (3), protonated dibenzylamine $\left(\mathbf{3}-\mathbf{H}^{+}\right)$and pseudorotaxane $\mathbf{4}-\mathbf{H}^{+}$(Table 1, entries 2-4) did not promote the Ritter reaction over 7 days at $40{ }^{\circ} \mathrm{C}$. Under the same reaction conditions, the threads in both protonated and deprotonated forms (2 and $\mathbf{2}-\mathbf{H}^{+}$, respectively) catalyzed the reaction equally effectively after 5 days (Table 1 , entries 5 and 6). The bistriazolium-based catalyst contained in the protonated rotaxane, $\mathbf{1}-\mathbf{H}^{+}$, catalyzed the reaction as effectively as the bis-triazolium-based unit of the threads (2 and $\mathbf{2}-\mathbf{H}^{+}$) affording 6a with good conversion (Table 1, entry 7). However, the deprotonated form of the rotaxane, 1, did not afford any product (Table 1, entry 8). This demonstrates that the inhibition of anion-binding catalysis by the rotaxane is caused by the macrocycle position in $\mathbf{1}$, which blocks the ability of the two triazolium groups to bind halide ions.

The progress of the Ritter reaction could also be controlled through in situ switching of the position of the macrocycle in the rotaxane catalyst (Table 1, entries 9-12). After 3 days of stirring $\mathbf{5 a}$ in the presence of $20 \mathrm{~mol} \%$ rotaxane in its inactive, deprotonated state (1), no conversion of $\mathrm{Ph}_{2} \mathrm{CHBr}$ to the acetamide product 6 a was observed. Upon addition of $\mathrm{CF}_{3} \mathrm{CO}_{2} \mathrm{H}(20 \mathrm{~mol} \%)$, the rotaxane catalyst was switched 'on', affording $6 \mathbf{a}$ in $60 \%$ yield within 5 days (Table 1 , entry 9). The activity of protonated rotaxane catalyst $\mathbf{1}-\mathbf{H}^{+}$could also be switched 'off' in situ by adding $\mathrm{NaOMe}(20 \mathrm{~mol} \%)$ to the reaction mixture (Table 1 , entry 11). Control experiments, reactions carried out with $\mathrm{NaOMe}(2 \mathrm{O} \mathrm{mol} \%)$ or $\mathrm{CF}_{3} \mathrm{CO}_{2} \mathrm{H}(2 \mathrm{O} \mathrm{mol} \%)$ in the absence of the rotaxanes, also confirmed that product formation requires the presence of the rotaxane organocatalyst (Table 1, entries 10 and 12). 
Under similar reaction conditions with other bromodiarylmethane derivatives $(\mathbf{5} \mathbf{b}, \mathbf{c})$, the use of protonated rotaxane $\mathbf{1}-\mathbf{H}^{+}$(anion-binding catalysis 'on') afforded the corresponding acetamide products $(\mathbf{6 b}, \mathbf{c})$ in comparable conversions to that found for $\mathrm{Ph}_{2} \mathrm{CHBr}$ (Table 2, entries 1 and 3 ). In contrast, the use of deprotonated rotaxane $\mathbf{1}$ (anion-binding catalysis 'off') did not produce any products in these reactions (Table 2 , entries 2 and 4 ).

Table 1. Investigation of the anion-binding-catalyzed Ritter reaction of bromodiphenylmethane with various potential catalysts and in situ switching of the catalytic activity. ${ }^{a}$

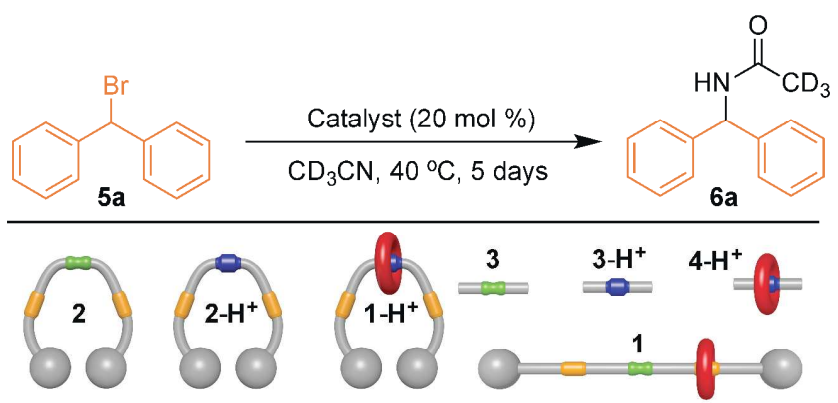

\begin{tabular}{ccc}
\hline Entry & Catalyst & $\begin{array}{c}\text { Conversion } \\
(\%)^{b}\end{array}$ \\
\hline 1 & - & $<1$ \\
2 & 3 & $<1$ \\
3 & $3-\mathbf{H}^{+}$ & $<1$ \\
4 & $\mathbf{4}-\mathbf{H}^{+}$ & $<1$ \\
5 & $\mathbf{2}$ & 54 \\
6 & $\mathbf{2}-\mathbf{H}^{+}$ & 55 \\
7 & $\mathbf{1}-\mathbf{H}^{+}$ & 69 \\
8 & $\mathbf{1}$ & $<1$ \\
9 & $\mathbf{1}+\mathrm{CF}_{3} \mathrm{CO}_{2} \mathrm{H}(20 \mathrm{~mol} \%)$ & $60^{c}$ \\
10 & $\mathrm{CF}_{3} \mathrm{CO}_{2} \mathrm{H}(20 \mathrm{~mol} \%)$ & $<1^{c}$ \\
11 & $\mathbf{1}-\mathbf{H}^{+}+\mathrm{NaOMe}(20 \mathrm{~mol} \%)$ & $<1^{d}$ \\
12 & $\mathrm{NaOMe}(20 \mathrm{~mol} \%)$ & $<1^{d}$ \\
\hline
\end{tabular}

${ }^{a}$ Reaction conditions: $36 \mu \mathrm{mol}$ of $\mathbf{5 a}$, and $7.2 \mu \mathrm{mol}$ of catalyst (20 mol\%) in $400 \mu \mathrm{L}$ of $\mathrm{CD}_{3} \mathrm{CN}$ at $40{ }^{\circ} \mathrm{C}$. ${ }^{b}$ Conversions determined after 5 days by ${ }^{1} \mathrm{H}$ NMR. ${ }^{c}$ Addition of $\mathrm{CF}_{3} \mathrm{CO}_{2} \mathrm{H}(20$ mol\%) to the reaction mixture. ${ }^{d}$ Addition of NaOMe (2O mol\%) to the reaction mixture.
Table 2. Scope of the anion-binding-catalyzed Ritter reaction of bromodiarylmethane derivatives $(5 \mathbf{b}, \mathbf{c})$ using rotaxanes $1-\mathrm{H}^{+}$and 1. $^{a}$

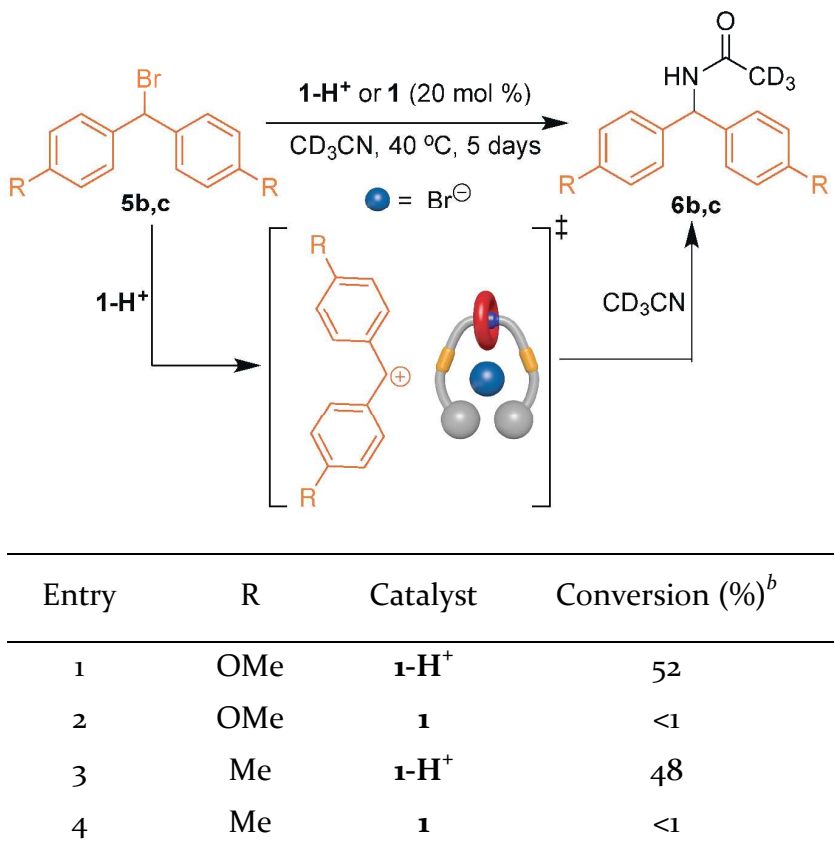

${ }^{a}$ Reaction conditions: $36 \mu \mathrm{mol}$ of $\mathbf{5} \mathbf{b}-\mathbf{c}$, and $7.2 \mu \mathrm{mol}$ of catalyst (1 or $\mathbf{1}-\mathbf{H}^{+}, 20 \mathrm{~mol} \%$ ) in $400 \mu \mathrm{L}$ of $\mathrm{CD}_{3} \mathrm{CN}$ at $40{ }^{\circ} \mathrm{C} .{ }^{b}$ Conversions determined after 5 days by ${ }^{1} \mathrm{H}$ NMR.

In order to further evaluate the effectiveness of the bistriazolium halide-binding groups in rotaxane $\mathbf{1}-\mathbf{H}^{+}$in catalysis, we investigated its performance for the in situ generation of oxonium ions via carbon-chlorine bond cleavage. $^{22}$ The catalytic activity of both rotaxanes $\left(\mathbf{1}-\mathbf{H}^{+}\right.$ and 1), and other potential reaction-promoting species, were studied in the reaction between 1-chloroisochroman (7) and the silyl ketene acetal 8a (Table 3). Other than the protonated rotaxane $\mathbf{1}-\mathbf{H}^{+}$, or the protonated or nonprotonated non-interlocked thread $\mathbf{2}-\mathbf{H}^{+}$and $\mathbf{2}$, none of the other potential reaction-promoting species (Table 3, entries 2-4) catalyzed the formation of product 9a. In contrast, both threads $\mathbf{2}$ and $\mathbf{2}-\mathbf{H}^{+}$catalyzed the reaction with excellent conversion (Table 3, entries 5 and 6). As before, the reaction promoted with the protonated rotaxane $\mathbf{1}-\mathbf{H}^{+}$(anion-binding catalysis 'on' state) is equally effective. In contrast, no reaction was observed using rotaxane $\mathbf{1}$ (anion-binding catalysis 'off' state). 
Table 3. Investigation of the anion-binding-catalyzed reaction of 1-chloroisochroman (7) and the ketene silyl acetal (8a) with various potential catalysts. ${ }^{a}$

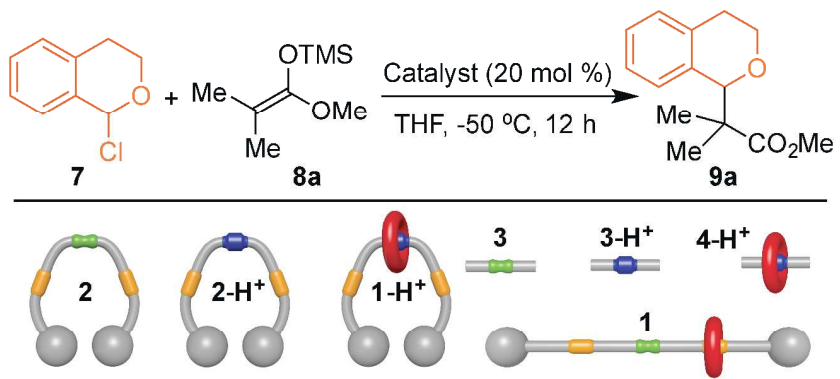

\begin{tabular}{ccc}
\hline Entry & Catalyst & Conversion $(\%)^{b}$ \\
\hline 1 & - & $<1$ \\
2 & 3 & $<1$ \\
3 & $3-\mathbf{H}^{+}$ & $<1$ \\
4 & $\mathbf{4}-\mathbf{H}^{+}$ & $<1$ \\
5 & $\mathbf{2}$ & 81 \\
6 & $\mathbf{2}-\mathbf{H}^{+}$ & 72 \\
7 & $\mathbf{1}-\mathbf{H}^{+}$ & 76 \\
8 & $\mathbf{1}$ & $<1$ \\
\hline
\end{tabular}

${ }^{a}$ Reaction conditions: $36 \mu \mathrm{mol}$ of $7,54 \mu \mathrm{mol}$ of $8 \mathrm{a}$ and 7.2 $\mu \mathrm{mol}$ of catalyst (20 mol\%) in $750 \mu \mathrm{L}$ of THF at $-50^{\circ} \mathrm{C}$. ${ }^{b}$ After 12 hours, the reaction was quenched by addition of $\mathrm{NaOMe}$ and the conversion determined by ${ }^{1} \mathrm{H}$ NMR.

The generality of rotaxane $\mathbf{1}-\mathrm{H}^{+} / \mathbf{1}$ as a switchable anionbinding catalyst was studied with diverse silyl ether nucleophiles (8b,d; Table 4). Protonated rotaxane $\mathbf{1}-\mathbf{H}^{+}$('on' catalyst) promoted the reaction between 7 and $\alpha$ unsubstituted silyl ether nucleophiles (8b and $\mathbf{8 d}$ ) with high conversions (Table 4, entries 1 and 3). However, hindered $\alpha$-disubstituted silyl enol ether 8c (Table 4, entry 5) afforded the corresponding aldehyde derivative in a poor yield. The change of the position of the macrocycle on the rotaxane allows for total control over the rate of the reactions, as the 'off' state of the system (1) does not exhibit any observable catalytic activity at all (Table 4, entries 2, 4 and 6).
Table 4. Scope of the anion-binding-catalyzed reaction between 1-chloroisochroman (7) and 8b-d with rotaxanes $1-\mathrm{H}^{+}$and $1 .{ }^{a}$

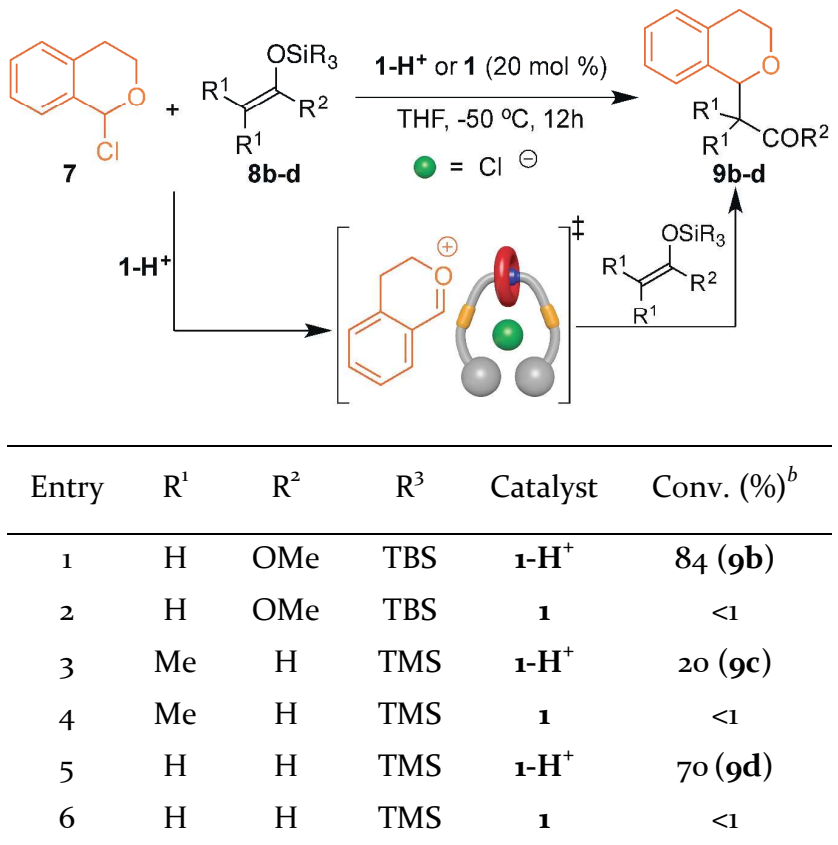

${ }^{a}$ Reaction conditions: $36.0 \mu \mathrm{mol}$ of $7,54.0 \mu \mathrm{mol}$ of $\mathbf{8 b}-\mathbf{d}$ and $7.2 \mu \mathrm{mol}$ of catalyst (1 and $\left.\mathbf{1}-\mathbf{H}^{+}, 20 \mathrm{~mol} \%\right)$ in $750 \mu \mathrm{L}$ of THF at $-50^{\circ} \mathrm{C} .{ }^{b}$ After 12 hours, the reaction was quenched by addition of $\mathrm{NaOMe}$ and the conversions determined by ${ }^{1} \mathrm{H}$ NMR.

Finally, the ability of rotaxane $\mathbf{1}-\mathbf{H}^{+} / \mathbf{1}$ to switch in situ between the two catalytic states (anion-binding catalyst and aminocatalyst), each promoting a different chemical transformation, was exploited to bring about a tandem reaction. The process consists first of an anion-bindingcatalyzed alkylation reaction between $\mathbf{7}$ and $\mathbf{8 d}$, followed by a nucleophilic addition of 10 via enamine activation of the intermediate aldehyde 9d (Scheme 1). An equimolar mixture of $\mathbf{7}$ and $\mathbf{8 d}(72 \mu \mathrm{mol})$ in the presence of $20 \mathrm{~mol} \%$ of protonated rotaxane $\mathbf{1}-\mathbf{H}^{+}$(anion-binding catalyst 'on') was stirred in THF at $-50{ }^{\circ} \mathrm{C}$, affording the alkylated product 9d with $70 \%$ conversion after $12 \mathrm{~h}$. After this time, $\mathrm{NaOMe}$ was added to quench the remaining excess of silyl enol ether and to switch 'on' the aminocatalyst state of the rotaxane (1) in situ. Subsequent addition of vinyl bissulfone 10 afforded compound $\mathbf{1 1}$ (50\% conversion after $48 \mathrm{~h}$ at r.t.) through enamine activation of 9d (see Supporting Information for experimental details). By controlling the order in which catalytic sites are revealed and concealed, dual-function switchable rotaxane catalyst 1$\mathrm{H}^{+} / \mathbf{1}$ is able to control the outcome of a tandem process, creating two new $\mathrm{C}-\mathrm{C}$ bonds, the first by anion-binding catalysis and the second by aminocatalysis via enamine activation.

\section{CONCLUSIONS}

A rotaxane that selectively masks or exposes a bistriazolium-based catalytic unit in response to acid/base acts as an effective switchable anion-binding catalyst. The 
rotaxane can effectively control the rate of Ritter and alkylation reactions by $\mathrm{C}-\mathrm{Br}$ or $\mathrm{C}-\mathrm{Cl}$ bond cleavage, respectively, either by adding the catalyst in its active form or by in situ switching. To the best of our knowledge these are the first examples of anion-binding catalysis of these reactions. The two catalytic functions of the system, an anion-binding catalyst and an aminocatalyst, can be selectively concealed or revealed and their activities switched on or off, enabling control over the product outcome of a tandem anion-binding-enamine catalytic reaction sequence.

Controlling the order in which catalytic sites are revealed and concealed by molecular machine multifunction catalysts represents a 'bio-like' strategy for molecular construction. ${ }^{3 e}$ Turning 'on' and 'off' different catalyst activities in response to a specific stimulus or analyte may be useful for promoting alternative reactions and product outcomes from mixtures of building blocks. ${ }^{\text {5a }}$

Scheme 1. Controlling the product outcome of a tandem reaction using switchable dual-function rotaxane 1$\mathrm{H}^{+} / 1$ : Switching in situ between the two catalytic units, anion-binding catalyst $1-\mathrm{H}^{+}$and aminocatalyst 1 . $^{\text {a }}$

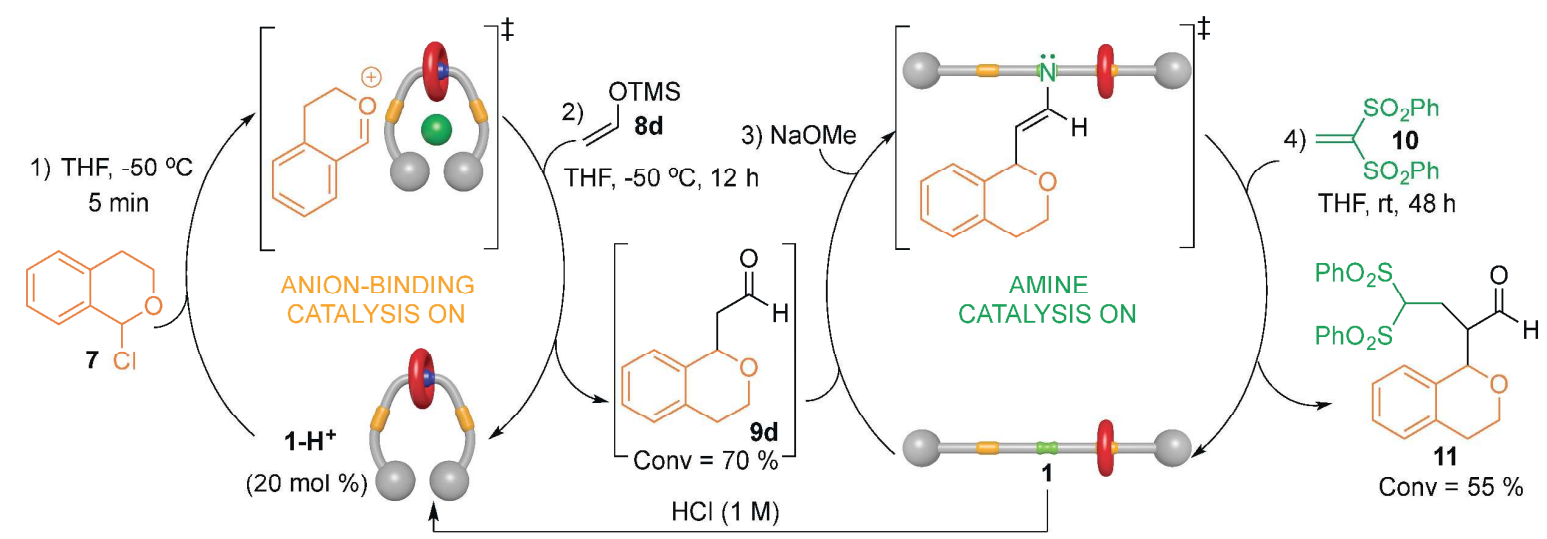

${ }^{a}$ See Supporting Information for experimental details.

\section{ASSOCIATED CONTENT}

Supporting Information.

Experimental procedures, spectral data for new compounds and ${ }^{1} \mathrm{H}$ NMR data for catalytic experiments and binding studies. This material is available free of charge via the Internet at http://pubs.acs.org.

\section{AUTHOR INFORMATION}

\section{Corresponding Author}

david.leigh@manchester.ac.uk.

\section{Notes}

The authors declare no competing financial interest.

\section{ACKNOWLEDGMENT}

This research was funded by the European Research Council (Advanced grant no. 339019) and the European Union's seventh Framework Program (FP7-PEOPLE-2013-ITN607602 'Hierarchical Self Assembly of Polymeric Soft Systems' SASSYPOL). We thank the Royal Society for a Newton International Fellowship (to TS) and a Research Professorship (to DAL).

\section{REFERENCES}

(1) (a) Yonath, A. Angew. Chem., Int. Ed. 2010, 49, 4340. (b) Ramakrishnan, V. Angew. Chem., Int. Ed. 2010, 49, 4355. (c) Steitz, T. A. Angew. Chem., Int. Ed. 2010, 49, 4381.
(2) Traut, T. W. Allosteric Regulatory Enzymes, Springer, New York, 2008.

(3) (a) Lüning, U. Angew. Chem., Int. Ed. 2012, 51, 8163. (b) Leigh, D. A.; Marcos, V.; Wilson, M. R. ACS Catal. 2014, 4, 4490. (c) Neal, E. A.; Goldup, S. M. Chem. Commun. 2014, 50, 5128. (d) Erbas-Cakmak, S.; Leigh, D. A.; McTernan, C. T.; Nussbaumer, A. L. Chem. Rev. 2015, 115, 10081. (e) Blanco, V.; Leigh D. A.; Marcos, V. Chem. Soc. Rev. 2015, 44, 5341. (f) Pan T.; Liu, J. ChemPhysChem 2016, 17, 1752. (g) Lewis, J. E. M.; Galli M.; Goldup, S. M. Chem. Commun. 2017, 53, 298.

(4) For representative examples of artificial catalysts that can be switched 'on' and 'off by a specific stimulus, see: (a) Würthner, F.; Rebek Jr., J. Angew. Chem., Int. Ed. Engl. 1995, 34, 446. (b) Yoon, H. J.; Kuwabara, J.; Kim, J.-H.; Mirkin, C. A. Science 2010, 330, 66. (c) Sohtome, Y.; Tanaka, S.; Takada, K.; Yamaguchi, T.; Nagasawa, K. Angew. Chem., Int. Ed. 2010, 49, 9254. (d) Berryman, O. B.; Sather, A. C.; Lledó, A.; Rebek Jr., J. Angew. Chem., Int. Ed. 2011, 50, 9400. (e) Wang, J.; Feringa, B. L. Science 2011, 331, 1429. (f) Mortezaei, S.; Catarineu, N. R.; Canary, J. W. J. Am. Chem. Soc. 2012, 134, 8054. (g) Neilson, B. M.; Bielawski, C. W. J. Am. Chem. Soc. 2012, 134, 12693. (h) Schmittel, M.; De, S.; Pramanik, S. Angew. Chem., Int. Ed. 2012, 51, 3832. (i) Schmittel, M.; Pramanik, S.; De, S. Chem. Commun. 2012, 48, 11730. (j) Wilson, D.; Branda, N. R. Angew. Chem., Int. Ed. 2012, 51, 5431. (k) Viehmann, P.; Hecht, S. Beilstein J. Org. Chem. 2012, 8, 1825. (l) Neilson, B. M.; Bielawski, C. W. Chem. Commun. 2013, 49, 5453. (m) Neilson, B. M.; Bielawski, C. W. Organometallics 2013, 32, 3121. (n) Osorio-Planes, L.; Rodríguez-Escrich, C.; Pericás, M. A. Org. Lett. 2014, 16, 1704. (o) McGuirk, C. M.; Stern, C. L.; Mirkin, C. A. J. Am. Chem. Soc. 2014, 136, 4689. (p) Blanco, V.; Leigh, D. A.; Marcos, V.; Morales-Serna, J. A.; Nussbaumer, A. L. J. Am. Chem. Soc. 2014, 
136, 4905. (q) Vlatković, M.; Bernardi, L.; Otten, E.; Feringa, B. L. Chem. Commun. 2014, 50, 7773. (r) Galli, M.; Lewis, J. E. M.; Goldup, S. M. Angew. Chem., Int. Ed. 2015, 54, 13545. (s) Martinez-Cuezva, A.; Saura-Sanmartin, A.; Nicolas-García, T.; Navarro, C.; Orenes, R.-A.; Alajarin, M.; Berná, J. Chem. Sci. 2017, 8, 3775 .

(5) For switching to unmask different catalytic sites within a molecule, see: (a) Beswick, J.; Blanco, V.; De Bo, G.; Leigh, D. A.; Lewandowska, U.; Lewandowski, B.; Mishiro, K. Chem. Sci. 2015, 6, 140. (b) Kwan, C.-S.; Chan, A. S. C.; Leung, K. C.-F. Org. Lett. 2016, 18, 976. For switching that unmasks different catalysts in multi-component systems, see: (c) De, S.; Pramanik S.; Schmittel, M. Angew. Chem., Int. Ed. 2014, 53, 14255. (d) Mittal, N.; Pramanik, S.; Paul, I.; De, S.; Schmittel, M. J. Am. Chem. Soc. 2017, 139, 4270.

(6) For orthogonal catalytic states of a single active-site, see: (a) Biernesser, A. B.; Delle Chiaie, K. R.; Curley, J. B.; Byers, J. A. Angew. Chem., Int. Ed. 2016, 55, 5251. (b) Teator, A. J.; Shao, H.; Lu, G.; Liu, P.; Bielawski, C. W. Organometallics 2017, 36, 490. (c) Semwal, S.; Choudhury, J. Angew. Chem., Int. Ed. 2017, 56,5556 .

(7) (a) Blanco, V.; Carlone, A.; Hänni, K. D.; Leigh, D. A.; Lewandowski, B. Angew. Chem., Int. Ed. 2012, 51, 5166. (b) Blanco, V.; Leigh, D. A.; Lewandowska, U.; Lewandowski, B.; Marcos, V. J. Am. Chem. Soc. 2014, 136, 15775.

(8) For rotaxanes incorporating catalytic centers, see: (a) Thordarson, P.; Bijsterveld, E. J. A.; Rowan, A. E.; Nolte, R. J. M. Nature 2003, 424, 915. (b) Tachibana, Y.; Kihara, N.; Takata, T. J. Am. Chem. Soc. 2004, 126, 3438. (c) Hattori, G.; Hori, T.; Miyake, Y.; Nishibayashi, Y. J. Am. Chem. Soc. 2007, 129, 12930. (d) Li, Y.; Feng, Y.; He, Y.-M.; Chen, F.; Pan, J.; Fan, Q.-H. Tetrahedron Lett. 20o8, 49, 2878. (e) Miyagawa, N.; Watanabe, M.; Matsuyama, T.; Koyama, Y.; Moriuchi, T.; Hirao, T.; Furusho, Y.; Takata, T. Chem. Commun. 2010, 46, 1920. (f) Berná, J.; Alajarín, M.; Orenes, R.-A. J. Am. Chem. Soc. 2010, 132, 10741. (g) Suzaki, Y.; Shimada, K.; Chihara, E.; Saito, T.; Tsuchido, Y.; Osakada, K. Org. Lett. 2011, 13, 3774. (h) Hoekman, S.; Kitching, M. O.; Leigh, D. A.; Papmeyer, M.; Roke, D. J. Am. Chem. Soc. 2015, 137, 7656. (i) Cakmak, Y.; Erbas-Cakmak, S.; Leigh, D. A. J. Am. Chem. Soc. 2016, 138, 1749. (j) Xu, K.; Nakazono, K.; Takata, T. Chem. Lett. 2016, 45, 1274. (k) Martinez-Cuezva, A.; Lopez-Leonardo, C.; Bautista, D.; Alajarin, M.; Berná, J. J. Am. Chem. Soc. 2016, 138, 8726.

(9) For some representative reviews on aminocatalysis, see: (a) MacMillan, D. W. C. Nature 2008, 455, 304. (b) Mielgo, A.; Palomo, C. Chem.-Asian J. 2008, 3, 922. (c) Melchiorre, P.; Marigo, M.; Carlone, A.; Bartoli, G. Angew. Chem., Int. Ed. 2008, 47, 6138. (d) Melchiorre, P. Angew. Chem., Int. Ed. 2009, 48, 1360. (e) Bertelsen, S.; Jørgensen, K. A. Chem. Soc. Rev. 2009, 38, 2178. (f) Grondal, C.; Jeanty, M.; Enders, D. Nat. Chem. 2010, 2, 167. (g) Marqués-López, E.; Herrera, R. P.; Christmann, M. Nat. Prod. Rep. 2o10, 27, 1138. (h) Cheong, P. H. -Y.; Legault, C. Y.; Um, J. M.; Çelebi-Öleçüm, N.; Houk, K. N. Chem. Rev. 2011, 111, 5042. (i) Nielsen, M.; Worgull, D.; Zweifel, T.; Gschwend, B.; Bertelsen, S.; Jørgensen, K. A. Chem. Commun. 2011, 47, 632. (j) Jensen, K. L.; Dickmeiss, G.; Jiang, H.; Albrecht, Ł.; Jørgensen, K. A. Acc. Chem. Res. 2012, 45, 248. (k) Parra, A.; Reboredo, S.; Alemán, J. Angew. Chem., Int. Ed. 2012, 51, 9734. (l) Meninno, S.; Lattanzi, A. Chem. Commun. 2013, 49, 3821. (m) Jiang, H.; Albrecht, Ł.; Jørgensen, K. A. Chem. Sci. 2013, 4, 2287. (n) Alemán, J.; Cabrera, S. Chem. Soc. Rev. 2013, 42, 774. (o) Jurberg, I. D.; Chatterjee, I.; Tannert, R.; Melchiorre, P. Chem. Commun. 2013, 49, 4869. (p) Albrecht, Ł.; Jiang, H.; Jørgensen, K. A. Chem.-Eur. J. 2014, 20, 358. (q) Matos Paz, B.; Jiang, H.; Jørgensen, K. A. Chem.-Eur. J. 2015, 21, 1846. (r) Zhang, L.; Fu, N.; Luo, S. Acc. Chem. Res. 2015, 48, 986. (s)
Halskov, K. S.; Donslund, B. S.; Matos Paz, B.; Jørgensen, K. A. Acc. Chem. Res. 2016, 49, 974.

(t) Dzięgielewski, M.; Pięta, J.; Kamińska, E.; Albrecht, Ł. Eur. J. Org. Chem. 2015, 677. (u) Marcos, V.; Alemán, J. Chem. Soc. Rev. 2016, 45, 6812. (v) Łągiewka, B.; Albrecht, Ł. Asian J. Chem. 2017, 10.1002/ajoc.201600616.

(10) For some representative reviews of anion-binding catalysis, see: (a) Zhang, Z.; Schreiner, P. R. Chem. Soc. Rev. 2oog, 38, 1187. (b) Beckendorf, S.; Asmus, S.; García Mancheño, O. ChemCatChem 2012, 4, 926. (c) Brak, K.; Jacobsen, E. N. Angew. Chem., Int. Ed. 2013, 52, 534. (d) Phipps, R. J.; Hamilton, G. L.; Toste, F. D. Nat. Chem. 2012, 4, 603. (e) Mahlau, M.; List, B. Angew. Chem., Int. Ed. 2013, 52, 518. (f) Seidel, D. Synlett 2014, 25,783 .

(11) (a) Coutrot, F.; Busseron, E. Chem.-Eur. J. 20o8, 14, 4784. (b) Coutrot, F.; Romuald, C.; Busseron, E. Org. Lett. 20o8, 10, 3741. (c) Clavel, C.; Romuald, C.; Brabet, E.; Coutrot, F. Chem.Eur. J. 2013, 19, 2982. (d) Chao, S.; Romuald, C.; FournelMarotte, K.; Clavel, C.; Coutrot, F. Angew. Chem., Int. Ed. 2014, 53, 6914. (e) Coutrot, F. ChemistryOpen 2015, 4, 556.

(12) For representative examples of anion-binding interlocked molecules, see: (a) Sambrook, M. R.; Beer, P. D.; Wisner, J. A.; Paul, R. L.; Cowley, A. R. J. Am. Chem. Soc. 2004, 126, 15364. (b) Lankshear, M. D.; Beer, P. D. Coord. Chem. Rev. 20o6, 250, 3142. (c) Sambrook, M. R.; Beer, P. D.; Lankshear, M. D.; Ludlow, R. F.; Wisner, J. A. Org. Biomol. Chem. 20o6, 4, 1529. (d) Lankshear, M. D.; Beer, P. D. Acc. Chem. Res. 2007, 40, 657. (e) Mullen, K. M.; Beer, P. D. Chem. Soc. Rev. 2009, 38, 1701. (f) Ayme, J.-F.; Beves, J. E.; Leigh, D. A.; McBurney, R. T.; Rissanen, K.; Schultz, D. Nature Chem. 2012, 4, 15. (g) Ayme, J.-F.; Beves, J. E.; Leigh, D. A.; McBurney, R. T.; Rissanen, K.; Schultz, D. J. Am. Chem. Soc. 2012, 134, 9488. (h) White, N. G.; Colaço, A. R.; Marques, I.; Félix, V.; Beer, P. D. Org. Biomol. Chem. 2014, 12, 4924. (i) Leigh, D. A.; Pritchard, R. G.; Stephens, A. J. Nat. Chem. 2014, 6, 978. (j) Cornes, S. P.; Davies, C. H.; Blyghton, D.; Sambrook, M. R.; Beer, P. D. Org. Biomol. Chem. 2015, 13, 2582. (k) Langton, M. J.; Marques, I.; Robinson, S. W.; Félix, V.; Beer, P. D. Chem.-Eur. J. 2016, 22, 185. (1) Brown, A.; Beer, P. D. Chem. Commun. 2016, 52, 8645. (m) Gilday, L. C.; White, N. G.; Beer, P. D. Supramol. Chem. 2016, 28, 62. (n) Danon, J. J.; Krüger, A.; Leigh, D. A.; Lemonnier, J.F.; Stephens, A. J.; Vitorica-Yrezabal, I. J.; Woltering, S. L. Science, 2017, 355, 159.

(13) For examples of shuttling induced by anion binding in rotaxanes, see: (a) Keaveney, C. M.; Leigh, D. A. Angew. Chem., Int. Ed. 2004, 43, 1222. (b) Lin, C.-F.; Lai, C.-C.; Liu, Y.-H.; Peng, S.-M.; Chiu, S.-H. Chem.-Eur. J. 2007, 13, 4350. (c) Huang, Y.-L.; Hung, W.-C.; Lai, C.-C.; Liu, Y.-H.; Peng, S.-M.; Chiu, S.-H. Angew. Chem., Int. Ed. 2007, 46, 6629. (d) Ng, K.-Y.; Félix, V.; Santos, S. M.; Rees, N. H.; Beer, P. D. Chem. Commun. 2oo8, 1281. (e) Barrell, M. J.; Leigh, D. A.; Lusby, P. J.; Slawin, A. M. Z. Angew. Chem., Int. Ed. 2008, 47, 8036. (f) Gassensmith, J. J.; Matthys, S.; Lee, J.-J.; Wojcik, A.; Kamat, P. V.; Smith, B. D. Chem.-Eur. J. 2010, 16, 2916. (g) Serpell, C. J.; Chall, R.; Thompson, A. L.; Beer, P. D. Dalton Trans. 2011, 40, 12052. (h) Caballero, A.; Swan, L.; Zapata, F.; Beer, P. D. Angew. Chem., Int. Ed. 2014, 53, 11854 .

(14) Pihko, P. M. Hydrogen Bonding in Organic Chemistry, Wiley-VCH, Weinheim, 2009.

(15) For some representative reviews on hydrogen bonding catalysis, see: (a) Schreiner, P. R. Chem. Soc. Rev. 2003, 32, 289. (b) Pihko, P. M. Angew. Chem., Int. Ed. 2004, 43, 2062. (c) Taylor, S.; Jacobsen, E. N. Angew. Chem., Int. Ed. 2006, 45, 1520. (d) Doyle, A. G.; Jacobsen, E. N. Chem. Rev. 2007, 107, 5713. (e) Knowles, R. R.; Jacobsen, E. N. Proc. Natl. Acad. Sci. USA 2010, 107, 20678. 
(16) For examples of (thio)ureas-based catalysts, see: (a) Taylor, M. S.; Jacobsen, E. N. J. Am. Chem. Soc. 2004, 126, 10558. (b) Yamaoka, Y.; Miyabe, H.; Takemoto, Y. J. Am. Chem. Soc. 2007, 129, 6686. (c) Knowles, R. R.; Lin, S.; Jacobsen, E. N. J. Am. Chem. Soc. 2010, 132, 5030. (d) De, C. K.; Seidel, D. J. Am. Chem. Soc. 2011, 133, 14538. (e) Ford, D. D.; Lehnherr, D.; Kennedy, C. R.; Jacobsen, E. N. J. Am. Chem. Soc. 2016, 138, 7860.

(17) Borovika, A.; Tang, P.-I.; Klapman, S.; Nagorny, P. Angew. Chem., Int. Ed. 2013, 52, 13424.

(18) (a) Schafer, A. G.; Wieting, J. M.; Fisher, T. J.; Mattson, A. E. Angew. Chem., Int. Ed. 2013, 52, 11321. (b) Beletskiy, E. V.; Schmidt, J.; Wang, X.-B.; Kass, S. R. J. Am. Chem. Soc. 2012, 134, 18534. (c) Diemoz, K. M.; Wilson, S. O. Franz, A. K. Chem.-Eur. J. 2016, 22, 18349.

(19) (a) Beckendorf, S.; Asmus, S.; Mück-Lichtenfeld, C.; García Mancheño, O. Chem.-Eur. J. 2013, 19, 1581. (b) Zurro, M.; Asmus, S.; Beckendorf, S.; Mück-Lichtenfeld, C.; García Mancheño, O. J. Am. Chem. Soc. 2014, 136, 13999. (c) García Mancheño, O.; Asmus, S.; Zurro, M.; Fischer, T. Angew. Chem., Int. Ed. 2015, 54, 8823. (d) Zurro, M.; Asmus, S.; Bamberger, J.; Beckendorf, S.; García Mancheño, O. Chem.-Eur. J. 2016, 22, 3785. (e) Fischer, T.; Bamberger, J.; García Mancheño, O. Org. Biomol. Chem. 2016, 14, 5794. (f) Marcos, V.; Stephens, A. J.; Jaramillo-Garcia, J.; Nussbaumer, A. L.; Woltering, S. L.; Valero, A.; Lemonnier, J.-F.; Vitorica-Yrezabal, I. J.; Leigh, D. A. Science 2016, 352, 1555. (g) Fischer, T.; Duong, Q.-N.; García Mancheño, O. Chem.-Eur. J. 2017, 23, 5983. (h) Zurro, M.; García Mancheño, O. Chem. Rec. 2017, 17, 485.

(20) (a) Kniep, F.; Jungbauer, S. H.; Zhang, Q.; Walter, S. M.; Schindler, S.; Schnapperelle, I.; Herdtweck, E.; Huber, S. M. Angew. Chem., Int. Ed. 2013, 52, 7028. (b) Jungbauer, S. H.; Huber, S. M. J. Am. Chem. Soc. 2015, 137, 12110. For C-X based activated reagents, see: (c) Walter, S. M.; Kniep, F.; Herdtweck, E.; Huber, S. M. Angew. Chem., Int. Ed. 2011, 50, 7187. (d) Kniep, F.; Walter, S. M.; Herdtweck, E.; Huber, S. M. Chem.Eur. J. 2012, 18, 1306. (e) Kniep, F.; Rout, L.; Walter, S. M.; Bensch, H. K. V.; Jungbauer, S. H.; Herdtweck, E.; Huber, S. M. Chem. Commun. 2012, 48, 9299.

(21) Using OriginPro 8.51 from OriginLab®, see Supporting Information.

(22) Reisman, S. E.; Doyle, A. G.; Jacobsen, E. N. J. Am. Chem. Soc. 2008, 130, 7198. 
Table of Contents artwork

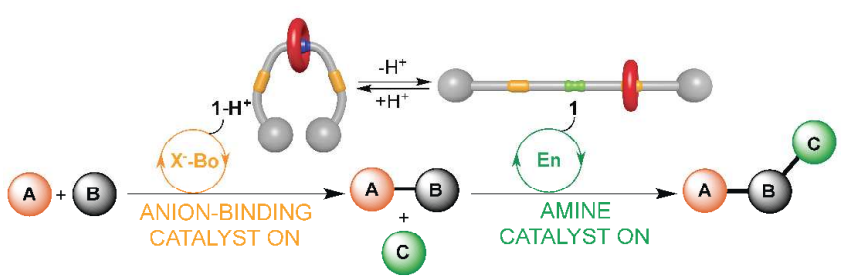

